\title{
Approaches to integrate land-use and transport planning. Analysing the political dimension of integrative planning
}

\author{
Meike Levin-Keitel $\bullet$, Irina Kim Reeker \\ Received: 25 October 2020 - Accepted: 24 March 2021 - Published online: 26 April 2021
}

\begin{abstract}
Spatial structures influence our travel distances between home, work, shopping or leisure and determine our mobility behaviour to a considerable extent. Although they are not the only determinants of our daily travel distances and times or our choice of different means of transport, the interrelations between spatial structures and mobility behaviour is often considered in the literature. Overall, the integration of land use and transportation planning is a key aspect in the shift towards sustainable mobility. This integrated planning approach is characterised, for instance, by increased cross-sector interaction, softened institutionalised boundaries between the two sectors of land-use and transportation planning, and shared cross-sector goals. In its implementation, however, this frequently postulated call for integration remains unclear. This paper uses the conceptual framework of the three dimensions of policy, polity and politics to empirically capture this integration in its various aspects. The two German cities of Dortmund and Hannover serve as case studies. The findings suggest that informal interaction (politics) between the two sectors is a necessary precondition for integration, while political will and cross-sectorally shared strategic goals (policy) are required to actually set the process of integration in motion. Ultimately, an approach is fully integrated when
\end{abstract}

Jun-Prof. Dr. Meike Levin-Keitel, Fakultät Raumplanung, Technische Universität Dortmund, August-Schmidt-Straße 10, 44221 Dortmund, Germany meike.levin-keitel@tu-dortmund.de

Irina Kim Reeker, Klimaschutzagentur Region Hannover gGmbH, Goethestraße 19, 30169 Hannover, Germany

ikreeker@gmail.com

(c) (1)

(c) 2021 Levin-Keitel; licensee oekom verlag. This Open Access article is published under a Creative Commons Attribution 4.0 International License. institutional structures (polity) are adapted in the sense of hierarchical coordination and the extensive elimination of sectoral boundaries.

Keywords: Integrated planning - transport planning conceptualisation of integration - policy - politics - polity Dortmund - Hannover

\section{Ansätze zur Integration von Flächennutzungs- und Verkehrsplanung. Analyse der politischen Dimension integrierter Planung}

\section{Zusammenfassung}

Räumliche Strukturen beeinflussen, welche Wege wir zwischen Wohnort, Arbeitsort, Einkaufsmöglichkeiten oder Freizeitvergnügen zurücklegen und bestimmen in erheblichem Maße unser Mobilitätsverhalten. Zwar sind sie nicht allein bestimmend über unsere täglichen Wegstrecken und Weglängen sowie unsere Wahl der Verkehrsmittel, doch wird der Zusammenhang zwischen räumlichen Strukturen und dem Mobilitätsverhalten in der Literatur stets aufgenommen. Schlussfolgernd ist die Integration von Flächennutzungs- und Verkehrsplanung ein zentraler Aspekt im Wandel hin zu einer nachhaltigen Mobilität. Dieser integrierte Planungsansatz zeichnet sich beispielsweise durch verstärkte sektorübergreifende Interaktion, aufgeweichte institutionalisierte Grenzen zwischen den beiden Sektoren der Flächennutzungs- und Verkehrsplanung sowie gemeinsame sektorübergreifende Ziele aus. In ihrer Umsetzung bleibt diese häufig postulierte Forderung nach Integration jedoch unklar. Dieser Beitrag nutzt den konzeptionellen Rahmen der drei Politikdimensionen Policy, Polity und Politics, um diese Integration in ihren verschiedenen Aspekten auch empirisch zu erfassen. Als Fallstudien dienen die beiden deutschen Städte Dortmund und Hannover. Ergebnis ist, dass informelle Interaktion (Politics) zwischen beiden Sektoren eine notwendige Voraussetzung für Integration ist, 
während politischer Wille und sektorübergreifend geteilte strategische Ziele (Policy) erforderlich sind, um den Prozess der Integration tatsächlich in Gang zu setzen. Letztlich ist ein Ansatz dann vollständig integriert, wenn institutionelle Strukturen (Polity) im Sinne einer hierarchischen Koordination und einer weitgehenden Aufhebung sektoraler Grenzen angepasst werden.

Schlüsselwörter: Integrierte Planung - Verkehrsplanung Konzeptualisierung von Integration - Policy - Politics Polity = Dortmund - Hannover

\section{Integration of land-use and transport planning - an frequently expressed claim}

The close relation between traffic avoidance, a modal shift to environmentally friendly modes of transport and the spatial structures in which mobility takes place is the subject of several studies. For instance, van Wee (2002: 269), Handy (2005: 1) and Ewing and Cervero (2001: 87) are all firmly convinced of the academic evidence demonstrating the impact of land use policy on travel behaviour. Still, there is insufficient knowledge and too few studies on how and in which exact way specific characteristics of the built environment or land-use changes influence physical activity and travel decisions (Van Wee 2002: 270; Handy 2005: 3; also Holz-Rau/Scheiner 2020: $398 \mathrm{ff}$.). A recent study analysed the specific links between certain land-use factors (e.g. regional accessibility, density, functional mix, roadway design) and planning objectives such as emission reductions and concluded that these factors can contribute considerably to reduced vehicle ownership and travel, per capita vehicle mileage and an increased use of alternative modes (Litman 2020: 3 f.). According to Ewing and Cervero (2001: 106), the variable of mode choice has received most academic interest in studies about the connection between land use and travel. Besides the built environment, however, they argue that this variable is also strongly influenced by socioeconomic factors (Ewing/Cervero 2001: 87).

Even though it remains indisputable that manifold different factors such as socioeconomic development or the size and density of a city or region have a strong impact on mobility behaviour, it seems obvious that the integration of land-use and transport planning is of central interest within the aim of sustainable mobility transitions. Their integration is undisputedly one of the key leverage points for sustainable mobility. Already in 1958, Colin Clark referred to transport as the "maker and breaker of cities" (Clark 1958). In addition to improving traffic routes and traffic safety, traffic planning's main tasks include the improve- ment of public transport, increasing the share of pedestrian and bicycle traffic as well as public transport, the reduction of noise, air pollutants and climate gases, and the realisation of a city or region of short distances. ${ }^{1}$ Rather than the traffic itself, the focal point of traffic planning can be seen as the daily life and demands of people and the economy and the long-term preservation of a healthy environment, working towards the aim of providing a framework in which these various demands can be reconciled (HolzRau 2018: 120). This systematises the goals of sustainable mobility development, including the three dimensions social affairs, economy and ecology. In this paper, we use the term 'sustainable' primarily with regard to its ecological dimension, referring to transport planning's aforementioned task to increase the share of environmentally friendly transport modes and reduce climate-damaging emissions.

Against this background, guiding principles for an integration of land-use and transport planning were developed decades ago, and postulated spatial development that saves transport and is oriented towards sustainable types of mobility (Beckmann 2020: 285). In discussions about sustainable urban development in the 1990s, the concept of a city of short distances emerged, describing an urban environment in which places of everyday life - such as workplaces, educational and supply facilities or recreational areas - can be reached within a short time and without being dependent on a (private) car (Beckmann/Gies/Thiemann-Linden et al. 2011: $21 \mathrm{f}$.). The planning principles behind this vision are accessibility, a functional mix of uses, density, good walking and cycling environments and generally a high-quality urban environment (Beckmann/Gies/Thiemann-Linden et al. 2011: 22; Gertz/Flämig/Gaffron et al. 2018: 305 f.). The scopes of action lie in densifying the urban structure by strictly prioritising inner rather than outer development and hence brownfield rather than greenfield development, enforcing changes in the use of areas and redistributing the road space in favour of public transport, walking and cycling (Curtis 2008: 109; Gertz/Flämig/Gaffron et al. 2018: 307 f.; Gil Solá/Vilhelmson/Larsson 2018: 5 f.). Looking beyond such measures of densification and spatial redistribution in urban structures, the strategic principle of publictransport-oriented development is relevant. The intention here is to locate urban growth in close proximity to public transport stations, whether in the form of housing settlements or other uses (Gertz/Flämig/Gaffron et al. 2018: 306). Today this approach is also discussed in similar concepts

\footnotetext{
1 https://www.umweltbundesamt.de/themen/verkehr-laerm/ verkehrsplanung/kommunale-verkehrsplanung\#integrierteverkehrsentwicklungsplanung-kommunenstellen-weichen (09.03.2021).
} 
like the 15-min-city, an access-focused urban perspective to reorganising urban life (e.g. Pozoukidou /Chatziyiannaki 2021).

In the past, it has often proved difficult to raise the potential of an integrated approach of land use and traffic, as both planning perspectives are characterised by a large number of different political levels of responsibility and departments (Beckmann 2020: 278, 285), with sometimes contradictory interests and goals.

The implementation of traffic-avoiding spatial structures places high demands on local decision-makers and planning officials. Besides "a shift away from a traditional transport policy paradigm", the implementation of such structures is influenced by "intra-organisational working relationships, professional cultures and institutionalised working practices" (Hrelja 2015: 2). Above all, the sectoral division of responsibilities between transport and land-use planning authorities is considered a crucial barrier to sustainable mobility development as it leads to competing agendas and hampers strategic thinking, creativity and innovation (Kennedy/Miller/Shalaby et al. 2005: 395; Hull 2008: 102; Stead 2008: 144). Consequently, there is growing demand for a holistic and integrated approach to land-use and transport planning on a political level as well (Hrelja 2015: 1; Kennedy/Miller/Shalaby et al. 2005: 395; Gil Solá/ Vilhelmson/Larsson 2018: 5). Precisely, policy integration is defined as "the management of cross-cutting issues in policy-making that transcend the boundaries of established policy fields, and which often do not correspond to the institutional responsibilities of individual departments" (Stead/ Geerlings 2005: 446).

Frequently mentioned barriers to integrated planning approaches include diverging professional practices, goals and jurisdictional borders between the involved sectors as well as mismatching time horizons of associated sectoral programmes (Hooghe/Marks 2003: 239; Stead 2008: 142; Stead/Geerlings 2005: 447; Te Brömmelstroet/Bertolini 2010: 86). Further, short political cycles lead to politicians being inclined to prioritise issues with shortterm effects that tend to generate public support more easily. Although there is often much political support expressed for integrated policy-making and cross-cutting issues like sustainable development, support for the subsequent implementation tends to be rather weak (Stead/Geerlings 2005: 450). A precondition for integration is hence the political courage to take unpopular decisions and redistribute funding towards sustainable land-use and mobility developments (UBA 2017: 9).

The close link between regional and transport planning is obvious. Taking a closer look at the planning reality in two German cities, this paper deals with the following research questions: What can sustainable transport develop- ment through integrated (regional) planning look like? How integrated are the two cities' planning approaches not only in terms of goals and targets, but also in procedural and culture-led aspects like informal networks and joint decisionmaking? We start from developing a conceptual framework inquiring into the political in the integration of land-use and transport planning according to the three well-established governance dimensions of polity, politics and policy (Section 2). Then, in the next step, we analyse the two German case studies, Dortmund and Hannover, and accordingly evaluate the level of integration (Sections 3 and 4). In the final section, we reflect on the results presented and draw a bigger picture of the role of integration in a transition towards sustainable mobility.

\section{Conceptual framework: Cooperation and integration in polity, politics and policy}

The aim of a more sustainable mobility system has attracted renewed attention in the context of climate change, $\mathrm{CO}_{2}$ emission reduction and the contribution the transport system is able to make here. One key issue discussed is a (re)organisation of our cities and regions to produce increasingly less traffic for everyday needs. The following conceptual framework builds upon this approach, emphasising the integration of land-use planning and transport planning for more sustainable outcomes in the built environment, especially neighbourhoods with mixed land uses, short distances and good accessibilities for everyday needs. The focal point of our analysis is therefore the political dimension and the negotiation processes relevant to the integration of land-use planning and traffic planning, focusing on outcomes in terms of policy papers or joint strategies rather than the direct outcomes in the built environment.

In general, integrating land-use and transport planning is a matter of intensified interaction between different sectors. Nevertheless, there are different levels of integration, not all of them follow the same logics, procedural ways forward and joint decision-making. Stead (2008: 140) considers that integration represents a higher level of joint decision-making than mere cooperation and coordination. Whereas cooperation refers to dialogue and information sharing between otherwise independent departments with the aim of improving the output for individual goals, coordination intends to adjust sectoral policies to make them more coherent and avoid conflict, contradictions and redundant duplicated work (Schermerhorn 1975: 847; Peters 1998; Stead/ Geerlings 2005: 445; Stead/Meijers 2009: 322). By including both cooperation and coordination (see Figure 1), an integrated approach applies the same goals for all the involved 


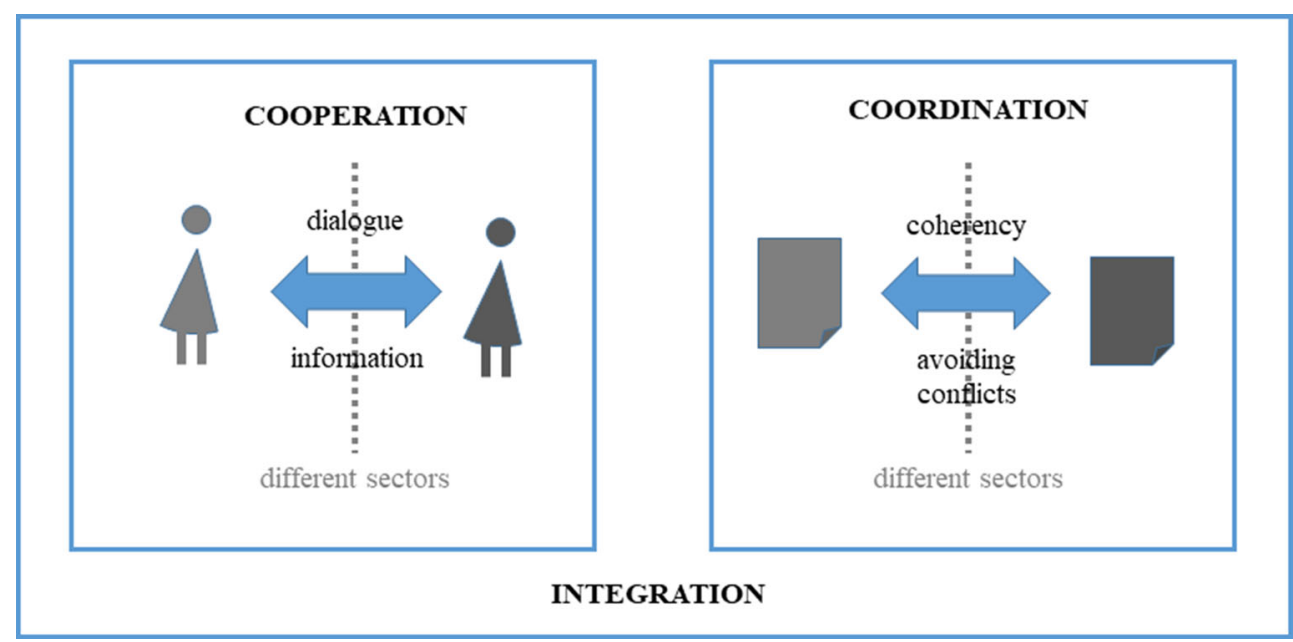

Figure 1 Cooperation, Coordination and Integration.

Source: the authors, following Stead (2008: 141)

sectors in order to create synergies between them; the intended outcome is one joint policy (Stead/Geerlings 2005: 451; Stead/De Jong 2006: 4; Stead/Meijers 2009: 322f.). Generally, a government's overall, cross-cutting goal (e.g. sustainable development, quality of life) leads to results that may strongly differ from the outcomes preferred by specific sectors (Stead/De Jong 2006: 4; Stead/Meijers 2009: $323 \mathrm{f}$.). However, the intense cross-sectoral interaction requires more resources in terms of formal and informal arrangements and dialogue formats. Therefore, the involved actors are less autonomous and more interdependent, with less clearly defined responsibilities and the setting of joint decision-making (Stead/Meijers 2009: $321 \mathrm{ff}$.).

An integrated planning approach expands the network of actors from within the local authority to include private stakeholders as well as the public (UBA 2017: 5). As public transport services are mostly delivered (semi-)privately in Germany, strong market regulation is necessary to guarantee sustainable development (Kennedy/Miller/Shalaby et al. 2005: 401; Dziekan/Zistel 2018: 350). With new forms of mobility like shared mobility or mobility as a service entering the market on a more business-oriented footing, the network of actors such as private stakeholders is even growing. An integration of these services with public transport in the form of mobility hubs has recently been discussed in academia and practice, as has its contribution to more sustainable multi-optional mobility behaviour (e.g. Utriainen/ Pöllänen 2018: 19). Besides involving the private operating companies, "it is only when there is sufficient public support for change, that action will take place" (Banister 2008: 76) since public support increases political will (Kennedy/Miller/Shalaby et al. 2005: 400; GPSM 2015: $10 \mathrm{f}$;; Thomas/Pojani/Lenferink et al. 2018: 1205).

In sum, Hrelja (2015: 11) is just one of those who argues that existing organisational structures and coordination mechanisms are often not beneficial for integration. Other scholars have focused on the investigation of integration as well, each with a different perspective and focus: Busscher, Tillema and Arts (2013: 492) focused on similar management approaches in transport and planning, Tennøy and Øksenholt (2018: 93) analysed changing structural conditions, and Lowe, Whitzman and Giles-Corti (2018: 180) concentrated on integrated policy-making.

Accordingly, the idea of a comprehensive understanding of the level of integration involves analysing precisely these barriers of integration, institutionalised in well-established governance forms and planning cultures in both sectors, land-use planning in general as well as transport planning. Therefore, the three dimensions of the political seem highly suitable: polity, politics and policy. In applying these terms

Table 1 The Three Political Dimensions of Polity, Politics and Policy.

\begin{tabular}{lll}
\hline Polity & Politics & Policy \\
\hline Formal Framework & (Informal) Processes & Content \\
- Organisational, institutionalised structures, de- & - Communication and negotiation processes & - Value and goal orientation \\
$\quad$ fined responsibilities & - Dynamic elements, temporal dimension & - Formulated in political pro- \\
- Formal instruments and procedural rules & - Informal instruments & grammes, visions, strate- \\
- Often regulated in legal frameworks & - Norms, traditions, ways of working & gies \\
\hline
\end{tabular}

Source: the authors, based on Hrelja (2015: 2), Schwedes (2018: $8 \mathrm{ff}$.) and Rode (2019: 42f.) 
directly to transport policy, Sager (2007: 270) similarly argues that "the trichotomy of polity, policy and politics is a useful, because parsimonious order for categorising the various factors influencing policy making that policy research identifies". While the polity dimension denotes the institutional organisation and structures as well as compositions of such structures, politics refer to the active process of implementation characterised by actor behaviour, actor interests and constellations of negotiations, and policy specifies the material elements or instruments emerging from and used in political processes, i.e. single measures, projects or political programmes (Sager 2007: $274 \mathrm{ff}$.). For the purposes of this research, we used an understanding of these terms that was specifically adapted to the integrated planning field of interest by scholars in land-use and transportation planning (Hrelja 2015: 2; Schwedes 2018: $8 \mathrm{ff}$;; Rode 2019: 42f.) (see Table 1).

Polity (form) aspects of integration refer to organisational structures and formal frameworks within which planning takes place, including factors such as institutionalised working practices and the distribution of responsibility and power across and within tiers of government (Hrelja 2015: 2; Schwedes 2018: 8; Rode 2019: 42). The intention in the polity dimension is to remove sectoral boundaries and establish joint responsibilities integrating transport concerns into formal land-use planning. Rode (2019: 48) and Stead (2008: 143f.) identify a central coordinating committee and hence some top-down hierarchical organisation that bundles all land-use and transport functions as crucial for an integrated planning approach. Within the framework of such an overarching steering unit, common visions and targets can be articulated and adhered to more easily (Mu/De Jong 2016: 62). Several scholars even make a case for establishing such a formal coordinating body on a regional level to promote cooperation between adjacent local governments (Kennedy/Miller/Shalaby et al. 2005: 398; Marsden/May 2006: 782; Pucher/Buehler 2008: 522; Gertz/Flämig/Gaffron et al. 2018: 314; Thomas/Pojani/ Lenferink et al. 2018: 1204). In order to soften or even remove jurisdictional boundaries and make actors more interdependent, institutionalised and constant, cross-sectoral teams should further be developed (Stead 2008: 144f.; Mu/De Jong 2016: 56).

Politics (processes) describe informal factors like daily working practices and negotiation processes which influence planning outcomes (Hrelja 2015: 2; Schwedes 2018: 9; Rode 2019: 43). The dynamic and temporal nature of the politics dimension (Rode 2019: 43) mostly distinguishes it from the institutionalised structures in the polity dimension, which are considered steady and non-temporary. Nevertheless, the institutionalised structures of the polity dimension alone do not guarantee integration (Stead/Geerlings 2005:
452). Rather, the networks within those structures, i.e. informal communication and negotiation processes, are crucial to facilitating integration (Kennedy/Miller/Shalaby et al. 2005: 398f.; Stead/Geerlings 2005: 449; Rode 2019: 54f.). In planning research, these local specific characteristics are often declared as planning culture within these institutionalised structures which enable or hinder integration (LevinKeitel/Othengrafen 2016: 84f.). This is associated with governments becoming part of a larger governance framework in which informal, soft instruments are applied and a multitude of stakeholders is involved (Marshall/Banister 2007: 1; Gawron 2010: 15; Knieling/Klindworth 2016: 6). Scholars assume that a working culture characterised by trust and collective responsibility facilitates integration, as it is a precondition for achieving consensus and shared objectives between all actors (Banister 2008: 79; Stead/Meijers 2009: 327). This can be strengthened through regular cross-sectoral meetings and systematic dialogue formats (e.g. common workshops or field trips) which raise mutual understanding as well as cross-sectoral capacity and build a common knowledge base (Stead 2008: 144; Hrelja 2015: 6; Koglin 2015: 59f.; Mu/De Jong 2016: 57). Further, multidisciplinary working groups and committees are beneficial (Stead/Geerlings 2005: 446; Stead 2008: 144). In this way, collective responsibility for cross-cutting issues is accepted more easily and such topics can be dealt with more effectively.

The third dimension of policy (content) denotes the specific content formulated in strategic programmes or visions through goals, values, guiding concepts and intended strategies (Schwedes 2018: 9). Whereas polity and politics collectively form the body of governance, the policy dimension describes the content-related outcome of the formal and informal actions in the other two dimensions. In the policy dimension, strategic documents such as political programmes, visions or (cross-)sectoral plans are a relevant instrument for integration and even sustainable development, among other things, since they can steer political decisions in the longterm (UBA 2017: 12; Gertz/Flämig/Gaffron et al. 2018: 315; Rode 2019: 43). Fully integrated policies are of crosssectoral nature and entail shared goals and principles that are not bound to the land-use or transport sector but break down these "traditional silos" (Curtis 2008: 108).

All the aforementioned factors and dimensions considerably promote integration in policy-making and planning. Yet, it is only through their parallel application that they take effect; no factor alone is sufficient to promote integration (Stead/Meijers 2009: 328). In order to demarcate integrated planning from cooperation or coordination, scholars emphasise the importance of increased formality; it is the institutional design which needs to be adapted in order to establish structures in which efficient and lasting levels of 
trust can be produced and reproduced between the actors (Stead 2008: 146f.; Mu/De Jong 2016: 57). Stead (2008: 146) even identifies cross-sectoral budgeting arrangements as crucial to distinguish the highest level of integration from coordination and cooperation.

\section{Case studies: Dortmund and Hannover - two German examples of sustainable mobility development}

Desktop research helped us to portray the current state of knowledge on the topic in question and build a conceptual framework. In the context of the case studies, we conducted seven semi-structured interviews with policy-makers and key stakeholders with respect to transport and landuse planning (three interviews for Dortmund; four interviews for Hannover). All seven interviewees were chosen and contacted due to their involvement in and contribution to the focus topics in the two case studies. In order to keep the discussions focused on the research questions, we developed an interview guide in advance, which was the same for each of the conducted interviews. The guide was composed mostly of open-ended questions, some of which were additionally accompanied by follow-up questions in order to enhance the precision of answers. We developed the interview guide based on the relevant factors that were identified in the conceptual framework. We analysed the accrued data using Mayring's (2000: 3) method of qualitative content analysis. The results from the interviews are anonymised. We selected the two cities Dortmund and Hannover as case studies due to certain similarities, which proved to be a good basis for comparison. These similarities include, for instance, that both cities have comparable population figures (size and density), are classified as higherorder centres and located in a larger region, and are designed as car-friendly cities with public transport systems characterised by a similar number of annual passengers. Further, we identified a need for action with regard to sustainable mobility development in both cities, e.g. in terms of exceeding air pollution limits. In the following, we briefly introduce the two cities in connection with their current situation of sustainable mobility.

\subsection{Dortmund: Car-friendly city in the polycentric Ruhr region}

The city of Dortmund is located in the densely populated Ruhr area, which is characterised by intense economic and institutional connections between its urban centres. The population of Dortmund has increased slightly in the past few years, reaching 603,609 at the end of 2019 (Stadt Dort- mund 2021: 20). The city's modal car share of $47 \%$ is significantly higher than the average of $38 \%$ for German cities of similar size (Stadt Dortmund 2018: 14). As a result of regularly exceeded annual average limits, Dortmund is among the 20 German cities with the worst nitrogen oxide values (Stadt Dortmund 2018: 17). Furthermore, in 2013, only $6 \%$ of the city's residents chose the bike for their everyday trips, which is less than half of the German average of 15\% (Stadt Dortmund 2014: 3; Stadt Dortmund 2018: 59). The local public transport network, consisting of suburban trains, light rails, an overhead railway and buses, is part of the Rhine-Ruhr Transport Association (Verkehrsverbund Rhein-Ruhr, VRR). Except for the suburban train, which falls under the authority of the VRR, the city of Dortmund is responsible for providing public transport and services are offered by the municipal transport company DSW21 (Stadt Dortmund 2004: 109f.; VRR 2017: 16; Dortmunder Stadtwerke 2019: 4).

\subsection{Hannover: Economic and cultural centre of the monocentric region}

As the state capital of Lower Saxony, the city of Hannover has pronounced regional and supra-regional economic and cultural relevance (Priebs 2014: 101; Region Hannover 2015: 28). Simultaneously, the city represents the centre of the Hannover Region, which is a strongly formalised regional model with formal political responsibility for several policy fields, among them spatial development and transport planning (Priebs 2014: 104). The city's administration remains independent and responsible for pedestrian and cycle traffic planning (Priebs 2014: 104). Besides the city of Hannover, which has a population of 556,695 (2020) and is constantly growing, the Hannover Region encompasses 20 surrounding municipalities (LSN 2020; Priebs 2014: 101).

After World War II, Hannover became a prime example of car-friendly urban development. This remains apparent in the city's car density, which is the third highest among the most populated German cities (Agora Verkehrswende 2020: 56). Nevertheless, almost two thirds of the population regularly choose a transport mode other than the private car $(\mathrm{Re}-$ gion Hannover 2018: 8). The local public transport system involves suburban train, light rail and buses and is part of Greater Hannover Transport (Großraum-Verkehr Hannover, GVH). Due to the exalted position of the Hannover Region, it is not the city of Hannover but the regional administration which is the commissioned authority for public transport (Region Hannover 2015: 38). Apart from the suburban train, services are provided by the subsidiary companies üstra (light rail and local buses) and regiobus (regional buses) 
(Landeshauptstadt Hannover 2011: 29; Region Hannover 2015: 38).

\section{Results: Comparing (Integrated) governance to sustainable mobility development in Dortmund and Hannover}

The following comparison depicts similarities as well as differences between the two approaches in the three governance dimensions of polity, politics and policy. Especially the aforementioned substantive differences with regard to governmental levels of authority of public transport need be borne in mind here.

\subsection{Polity}

A substantive difference between the two case studies in the polity dimension is the governmental level where the strategic coordination of sustainable mobility development activities takes place. In Hannover, central strategic planning tasks, including spatial and public transport planning, are bundled on the regional level. The city of Hannover rather works on district level and, for example, plans cycle and foot traffic (Interview H6). ${ }^{2}$ Hence, as the commissioned authority for public transport planning, the Hannover Region sets the strategic course for sustainable mobility development and can be described as a notable exception in Germany due to its regionally adopted transport development plan (Gertz/Flämig/Gaffron et al. 2018: 314). The powerful role of the Hannover Region is strongly supported by the city of Hannover as well as by the surrounding municipalities. This enables the regional administration to use its formal regional plans effectively in order to steer local activities in a strategic direction - not only have the regional plans been used to restrict the development allowed in the regional municipalities over a defined period, but they can also reserve planned routes on a legally binding basis for possible extensions of rail-bound public transport (Priebs 2014: 107; Interview H5). The fact that all local land-use plans must be approved by the region further strengthens the influence of the Hannover Region. In this position, the region mediates between (potentially conflicting) local interests, while still proving sensitive to the local planning priorities. This means that long-term planning principles can be pursued more easily in the region. Further, the central performance of spatial and public transport planning tasks on the regional

\footnotetext{
2 See table at the end relating the interview keys to the respective
} interview partners. level enables a targeted coordination of the main regional commuter flows.

The city of Dortmund, in turn, is an autonomous city in the larger Ruhr context, which itself coordinates landuse and transport planning on the local level. There is no formal coordinating body on the regional level to deal with the Ruhr area's polycentric nature and steer local action in a strategic direction - the regional (mobility) policies currently being developed will be of informal character and will not be binding for the municipalities concerned, instead implementation will rather be based on voluntary commitments.

Turning to the institutional responsibilities within the local administration of Dortmund, formal land-use and transport planning are not fully separated in structural terms. They are dealt with in different divisions, but both are part of the overarching Urban Planning and Building Regulations Office that is responsible for the two sectors (Interviews DO1 and DO2). ${ }^{3}$ The hierarchical structure in terms of the institutional subsumption of both planning areas in one overarching office removes barriers to cross-sectoral interaction and facilitates the overseeing and coordination of actions. Nevertheless, structural sectorisation in the form of clearly defined responsibilities is still prevalent, resulting in a situation in which the actors are still largely autonomous and only to a limited extent interdependent.

In comparison, the hierarchical and coordination structures within Hannover's regional administration are less straightforward. The two relevant divisions of regional planning that strongly influence land-use and transport development belong to two different higher-level offices and departments. ${ }^{4}$ Hence, there is no overarching coordinating authority for the two sectors which can formally steer the sectoral actions. Nevertheless, boundaries between the sectors are partly removed in the regional administration due to one member of staff working $50 \%$ in each of the relevant divisions (Interviews H6 and H7). Originally, the employee was recruited as a transport planner in the regional planning division in order to define suitable routes for future rail-bound public transport extensions. After the routes were identified, their realisation is now implemented in the division of transport development, which is why $50 \%$ of the working hours of the employee were transferred to that division (Interview H7). The hiring of a transport planner

\footnotetext{
3 https://www.dortmund.de/media/p/stadtplanungs_und_ bauordnungsamt/stadtplanung_bauordnung_ downloads/Organigramm.pdf (10.03.2021).

${ }^{4}$ https://www.hannover.de/Media/01-DATA-Neu/Downloads/ Region-Hannover/Verwaltung/Aufbauorganisation-derVerwaltung-der-Region-Hannover (10.03.2021).
} 
by the division of regional planning in itself indicates increased cross-sectoral capacity while the simultaneous employment in both divisions shows that sectoral boundaries have been softened and an integrated way of thinking exists. Taking into consideration the aforementioned superordinate climate-related objectives of the region, the climate protection unit of the regional administration is further worth mentioning. This is a cross-sectoral body that has bundled and coordinated all regional climate activities since 2013 in a non-hierarchical way. ${ }^{5}$

Consequently, a certain hierarchy exists in both case studies on different scales (i.e. within the administration in Dortmund and between the regional and local levels in Hannover). Sectoral boundaries still largely prevail in Dortmund's administration, although the two relevant divisions are subsumed in one overarching office. In Hannover, the relevant divisions belong to different higher-level departments, but there are noteworthy institutionalised cross-sectoral structures in place.

\subsection{Politics}

We found that the most significant differences between the two selected case studies concern the practices in the politics dimension. Whereas extensive network structures were identified in Dortmund, those could not be found in the daily working practices in Hannover.

Twice a week, regular meetings take place between all divisions of the Urban Planning and Regulations Office in Dortmund's local administration, i.e. including the divisions of formal land-use planning and mobility planning (Interview DO2). An administrative meeting with the Civil Engineering Office is further arranged approximately every eight weeks. About once a month, informal expert events address different topics (in some cases also transport or integrated urban planning) in an open and network-oriented format including concerned and/or interested administrative staff as well as architects or university employees (Interviews DO2 and DO3). These formats represent what was previously defined as informal networks and contribute substantially to creating a common knowledge base and maintaining trust, eventually resulting in a sense of shared responsibility. Further, both relevant divisions in Dortmund seem to employ people with a highly integrated and cross-sectoral way of thinking who are, moreover, strongly supported in their work by the head of the overarching office (Interview DO3).

\footnotetext{
5 https://www.hannover.de/Leben-in-der-Region-Hannover/ Umwelt-Nachhaltigkeit/Klimaschutz-Energie/KlimaschutzregionHannover/Aktivit\%C3\%A4ten-der-Region-Hannover (10.03.2021).
}

Great efforts to support integrated planning are also put into the current elaboration of the transport development plan in Dortmund. A long-term mixed working group including members from the administration, politics, civil society and business discusses all contents and measures suggested by the administration and makes recommendations for the ongoing process (Stadt Dortmund 2018: 4). The interviewees emphasised the high quality of the group's working sessions with intensive discussions in small groups as well as recognisable common learning processes despite the many different interests among the members (Interviews DO1, DO2 and DO3). In addition to the working group, workshops on certain topics (e.g. pedestrian traffic, traffic safety) take place, some using an administration-internal format and some with the involvement of external actors such as university employees or schools. The workshops rather address the level of measures, but in some cases also have a strategic focus (Interview DO3).

Similar to Dortmund's practices in the context of the transport development plan, cross-sectoral working groups and topic-specific workshops to discuss overall intentions and goals are also common in Hannover when a policy is being developed (Interviews H5 and H6). In such cases, interdepartmental policy teams or working groups are usually established and interaction between the sectors appears to be efficient (Interviews H5 and H6). Nevertheless, this does not refer to everyday working practices, where the interviews suggest that interaction between the sectors within the regional administration apparently used to be more intensive than it is today (Interviews H5 and H7). In the course of current daily work, there is no regular exchange format between the divisions of transport planning and the regional planning department. Instead, meetings take place on demand and are topic-related (Interviews H5, H6 and H7). One interviewee argued that the lack of a regular exchange might just indicate that there is currently no need for it, and that stable and high trust levels and a common knowledge base have already been established over the long period of pursuing the same goals (Interview H7). Yet, at the moment, there are no network structures in place in the regional administration of Hannover. Similarly, between the regional and the local tiers of government, no regular (cross-sectoral) meetings or working practices were mentioned in the interviews or found in other sighted sources. Exchange here also primarily occurs in the context of specific policy developments through the local administration's involvement in the above-mentioned working groups and workshops ( $\mathrm{Re}$ gion Hannover 2011: 10f.).

Hence, when a new policy is in preparation, both city administrations seem to focus on reciprocal cross-sectoral involvement through temporary working groups and workshops. In daily planning practice, however, Hannover's re- 
gional administration counts less on informal network structures. For Dortmund, due to less formal integration, informal network structures play a crucial role.

\subsection{Policy}

Looking at the policy dimension, we found that the same planning principles exist in both contexts, but that the driving forces and underlying paradigms of transport planning differed for a long time and are only now identical. Both case studies' formal spatial plans mention the three planning principles: (a) decentralised concentration, (b) harmonisation of settlement and transport planning through public transport-oriented development and (c) prioritisation of inner over outer development. Moreover, in both cities, the current driving forces for sustainable mobility development are climate-related goals aimed at a reduction of $\mathrm{CO}_{2}$, noise emissions and nitrogen oxides. The substantial difference between the two case studies in this regard is that Dortmund has only recently shifted towards this climate-related focus.

Efforts in Dortmund were long driven by ongoing structural change in the polycentric Ruhr region that posed various new challenges for local land use (Stadt Dortmund 2004: 14, 16, 39). The preparatory land-use plan from 2004 along with six supporting sectoral policies, among them a transport development plan (Verkehrsentwicklungsplan), was primarily aimed at further establishing Dortmund as a business location, focal point of employment and ultimately a relevant higher-order centre in the Ruhr metropolitan region (Stadt Dortmund 2004: 14). In this context, the three guiding principles of prioritisation of inner over outer development, decentralised concentration (here termed the multicentre model) and harmonisation of settlement and transport development were mentioned repeatedly (Stadt Dortmund 2004: $43 \mathrm{ff}$.). Nevertheless, the policies were mainly driven by the above-mentioned economic objectives of strengthening the city's position in the region and in this regard, the interviewees pointed out an enduringly strong car-orientation (Interviews DO1, DO2 and DO3). In line with the aforementioned planning principles but also with the economic driving factors, public transport also seems to have been seen more as a competitive tool for urban development. Social and environmental aspects along with walking and cycling were rather neglected until lately, when the interviews suggest that noticeable political rethinking occurred - shifting away from the traditional mobility-enhancing transport policy paradigm towards an increased political will to act on sustainable mobility development (Interviews DO1, DO2 and DO3). This is why a new transport development plan process was launched in 2016, setting a strong focus on cycling as well as electromo- bility with the main objectives of emission reduction and compliance with defined air pollution limits (Stadt Dortmund 2018: 18f.; Interview DO3). In fact, the ongoing process shows a promising strategic orientation, comprising a comprehensive target concept and eight sub-concepts that are supposed to incorporate the goals of the target concept and are to be established with close connections to each other (Stadt Dortmund 2018: 20). However, the resulting transport development plan remains a sectoral policy that is not embedded in any cross-sectoral or spatial (integrated) policy context in which the goals could be incorporated. Further, since regional (transport) policies for the Ruhr region are only now being developed (Interview DO1), there is currently no overarching instrument to guide development in a strategic direction.

In 2010, the Hannover Region adopted the aim of becoming a role model for sustainable action and a climateneutral region by 2050 as one of seven strategic superordinate objectives, which represent guidelines for all actions taken on the regional level. ${ }^{6}$ Within this overarching crosssectoral context of climate-related ambitions, the regional and local levels developed informal sectoral transport development plans in 2011, both prioritising measures with a high potential for emission reduction (Landeshauptstadt Hannover 2011: 3, 20; Region Hannover 2011: 1). Emission reduction $\left(\mathrm{CO}_{2}\right.$, nitrogen oxides, noise) hence represents the superordinate goal for sustainable mobility development in Hannover (Interview H6). Further, especially the regional transport development plan recognised public transport as the backbone for realising a region of short distances, placing a strong focus on public transport promotion as well as on prioritisation of inner over outer development (Region Hannover 2011: $27 \mathrm{f}$.). In doing so, the informal plan complements Hannover's formal regional plans, which for a long time already pursued the two leading principles of decentralised concentration and integration of transport and settlement planning (Region Hannover 2011: 8, 40; Priebs 2014: 107). In fact, in the 1960s Hannover's first regional plan already linked settlement developments to rail-bound public transport extensions. Further, a three-tier hierarchy of settlements with the city of Hannover at the centre was developed and clear priority was given to inner rather than outer development (Priebs 2014: 106f.; Region Hannover 2016: 20). Leite, Leiren, Zibell et al. (2008: 142) hence argue that the Hannover Region has a long tradition of pursuing integrated planning principles, favoured by strong political consensus. Accordingly, not only are Hannover's

\footnotetext{
6 https://www.hannover.de/Leben-in-der-Region-Hannover/ Umwelt-Nachhaltigkeit/Klimaschutz-Energie/KlimaschutzregionHannover/Aktivit\%C3\%A4ten-der-Region-Hannover (10.03.2021).
} 
transport policies embedded in the cross-sectoral context of climate ambitions that are shared by all sectors, but they are also mutually enforcing and supported by the continuous pursuit of integrated planning principles.

The regional contexts in which the two case studies are embedded thus seem to make an important difference. Although the same planning principles existed for both cities, the driving forces and underlying paradigms of transport planning differed for a long time. Due to the region's monocentric nature, Hannover was able to base its planning on qualitative (i.e. environmental and social) aspects as well as on cross-sectorally shared targets much earlier than was the case for Dortmund.

\section{Discussion and reflection: Looking beyond the claim of integrated planning - outcomes in a wider picture}

The conducted research has shown that traditional governance approaches with clearly separated policy sectors and little intersectoral interaction are not appropriate for addressing the issue of sustainable mobility development. We referred to a strand of the literature that suggests that integrated cross-sectoral problem-solving strategies are necessary to facilitate long-term strategic development towards sustainable urban mobility. Integrated land-use and transport planning requires effective governance bodies with modified organisational structures and network formats. With the aim of 'looking behind the curtain' and analysing integrative approaches, we identified facilitating factors in the three governance dimensions polity, politics and policy. The policy dimension requires a paradigm shift, resulting in an increased focus on cross-cutting goals such as sustainable development instead of sectoral targets, and giving more weight to qualitative (i.e. social and environmental) aspects of the transport system. In order to implement these policies, the increased removal of institutional barriers (polity) as well as extensive and flexible network structures (politics) between the land-use and transport sectors are crucial.

With regard to the two case studies' approaches, it first needs to be taken into account that public transport planning takes place on different governmental levels in the two different contexts, namely on the regional level for Hannover and the local level for Dortmund. In their current approach, both case studies aim to reduce climate-damaging emissions, primarily by promoting sustainable transport modes. However, we found that Dortmund and Hannover are at different stages in the integration process. We argue that (a) the generally polycentric character of the Ruhr region and (b) the lack of a strategic steering authority on the regional level kept the city of Dortmund from changing its transport planning paradigm for quite some time. Consequently, the climate-friendly focus has only been recently developed in Dortmund. In turn, the general regional management combined with the monocentric nature of the Hannover Region initiated and facilitated the consideration of integrated planning at an early stage. Not only did the former make it easier to formulate cross-sectoral strategic climate targets for the whole region, but the strong power of the Hannover Region also enabled the alignment of all concerns with the strategic goals and the efficient coordination of local interests. Apart from the differences in formal regional coordination, both case studies still show a fairly high degree of sectoralisation in their administrations' institutional design (polity). In conclusion, the mono- or polycentric nature of the two case studies does not automatically lead to better or worse integration in terms of politics - this simplistic understanding does not do justice to the complex structural conditions. However, the two relevant divisions in the Hannover Region are closely linked by an employee working for both sectors who thus integrates regional planning and transport planning in person. The politics dimension revealed the biggest difference between the two case studies: networks of cross-sectoral working relationships are much more extensive in Dortmund than in Hannover, where informal interaction mostly takes place in a topic-related way (see Figure 2).

We conclude that soft governance instruments in informal and flexible network structures (politics) are a necessary precondition and assumedly a first step towards integration, whereas political will, shared strategies (policy) and finally institutional design (polity) are necessary to ensure the real integration of planning approaches at some point. We identify true political will to be essential for realising a sustainable mobility future. This simultaneously represents a potential obstacle due to the assumed structural problem of democratic systems to implement longterm goals that do not generate short-term election votes. Leite, Leiren, Zibell et al. (2008: iv) argue that "the selfcontained political and administrative will to pursue a regional planning concept" was one of the main success factors in the Hannover Region. Without political will, a paradigm shift in transport planning simply cannot be realised since the administration cannot act in an integrated way without being supported by high level politicians (Interview H6). The interviews revealed that politicians in Dortmund prioritised the car for a long time, which kept the city from changing its transport planning paradigm and thus the focus of its policy dimension. We further assume that no institutional condition of the polity dimension will help if 


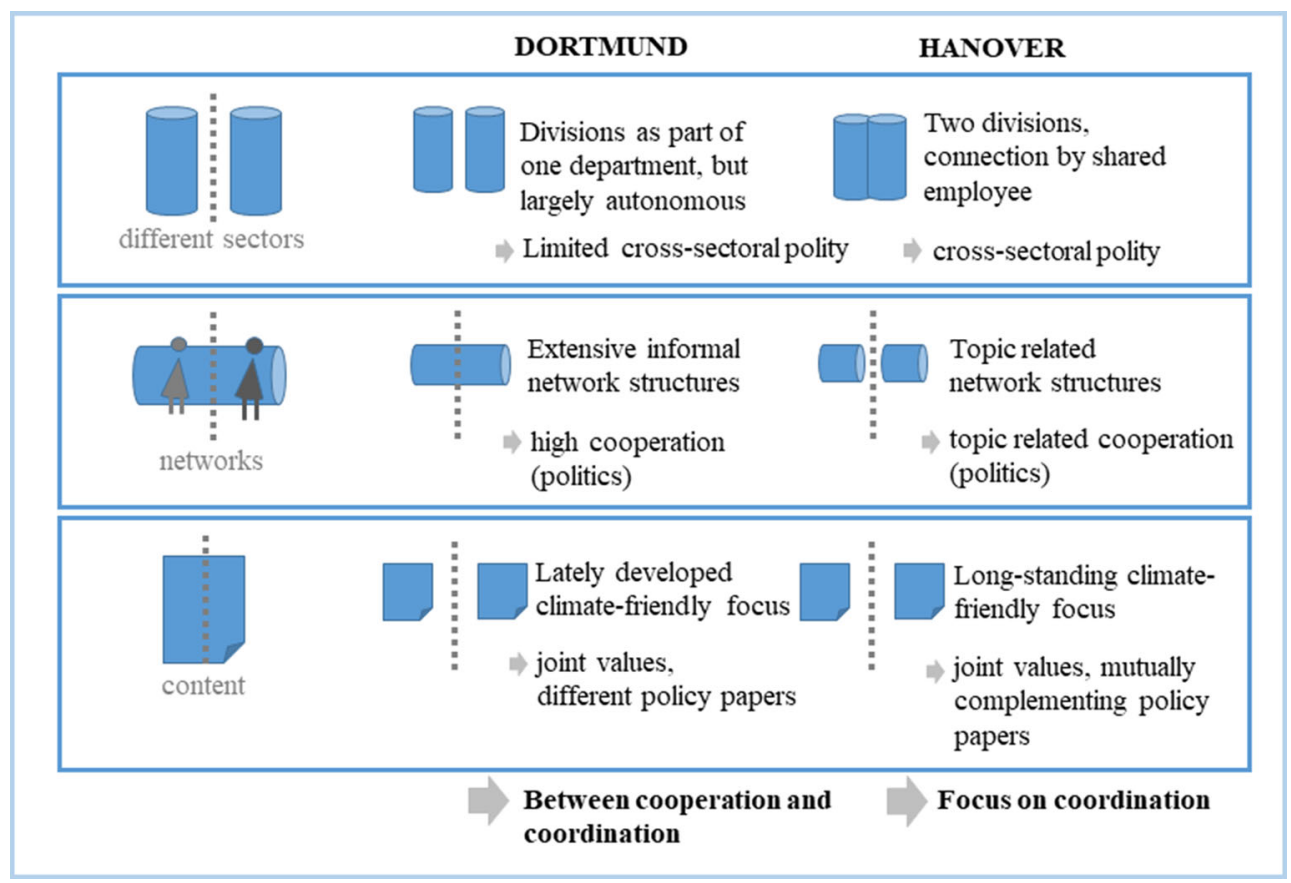

Figure 2 Polity, Politics and Policy in Dortmund and Hannover

political consensus on sustainable mobility development is not existent.

We detected that both case studies are aware of the fact that traditional planning approaches with clear sectoral boundaries no longer work when targeting sustainable mobility development and that a more coordinated, integrated approach is required. Despite the case studies' different starting situations, they can still learn from each other in some way. For Dortmund, the main field of action lies in the policy dimension, where overarching strategic targets for sustainable development at city-wide level - similar to the climate-related targets in the Hannover Region would provide guidelines for further actions in all policy sectors. In this way, transport concerns could be embedded in a cross-sectoral context and additionally integrated into formal spatial plans. Further, more institutionalised intersectoral structures should be implemented in Dortmund. Especially the example of the employee working in two relevant divisions in Hannover can serve as a positive role model for Dortmund here. Similar structures could increase the intersectoral capacity and provide more possibilities for activity coordination.

Hannover, in turn, can learn considerably from Dortmund's politics dimension. It seems that the Hannover Region is to some extent resting on its past success in developing high trust levels, collective responsibility and a common knowledge base between the relevant sectors. However, such collective behaviour needs to be reproduced over and over again in order to maintain efficient network structures. In this regard, Hannover can learn from Dortmund's approach with regular cross-sectoral meetings and ongoing dialogue formats. In conclusion, the monocentric spatial embeddedness of Hannover shows some advantages in the institutional arrangements at a first glance, although Dortmund and its more informal cross-sectional approach provide insights into a less formalised integrated approach which is in no way inferior to the former.

Stead (2008: 146) argues that perfect integration is not possible and that a certain degree of incoherence is unavoidable in a political system involving a multitude of actors with different priorities, interests and instruments. Although there is wide consensus on integrated planning being favourable, Stead and Meijers (2009: 329) also identified generally poor understanding of the concept itself and of how it can be achieved. As a matter of fact, they referred to it as "fuzzy, rather like the concept of sustainable development" (Stead/Meijers 2009: 329). So, with our analysis of the integrated planning approaches in Dortmund and Hannover we aim to shed some light on these often-unseen practices behind closed doors, to make the concept of integration less fuzzy and easier to grasp.

A limitation to the comparability of the two case study cities can be identified with regard to the different governmental levels (regional and local) with authority over public transport planning; this leads to differences between the possibilities and capacities available to the cities for the implementation of integrated planning. In this regard, a stronger consideration of the vertical component of inte- 
grated planning, i.e. the study of structures and practices between governmental tiers, holds great potential for future research. Moreover, we only superficially touched upon the involvement of actors from outside the administration, e.g. the public and the public transport operating companies. Subsequent research could reveal the specific interactions in all existing networks and deal, for instance, with the effects of public participation on integrated planning processes. Moreover, further research is required in terms of a detailed analysis of the relevant interdependencies between transport and other sectors, e.g. retail or housing development.

\section{List of Interviews}

\begin{tabular}{|c|c|c|}
\hline $\begin{array}{l}\text { Interview } \\
\text { Key }\end{array}$ & Interview Partner & Date \\
\hline D01 & $\begin{array}{l}\text { Urban Planning and Building Regula- } \\
\text { tions Office, City of Dortmund }\end{array}$ & 07.01 .2020 \\
\hline DO2 & $\begin{array}{l}\text { Urban Planning and Building Regula- } \\
\text { tions Office, City of Dortmund }\end{array}$ & 07.01 .2020 \\
\hline D03 & $\begin{array}{l}\text { External planning office providing } \\
\text { technical support for the process of } \\
\text { local mobility planning in Dortmund }\end{array}$ & 08.01 .2020 \\
\hline H5 & $\begin{array}{l}\text { Regional Planning and Development } \\
\text { Office, Hannover Region }\end{array}$ & 20.01 .2020 \\
\hline H6 & $\begin{array}{l}\text { Transport Development and Manage- } \\
\text { ment, Hannover Region }\end{array}$ & 21.01 .2020 \\
\hline $\mathrm{H} 7$ & $\begin{array}{l}\text { Regional Planning and Development } \\
\text { Office, Hannover Region }\end{array}$ & 03.02 .2020 \\
\hline
\end{tabular}

\section{References}

Agora Verkehrswende (2020): Städte in Bewegung. Zahlen, Daten, Fakten zur Mobilität in 35 deutschen Städten. Berlin.

Banister, D. (2008): The sustainable mobility paradigm. In: Transport Policy 15, 2, 73-80. https://doi.org/10.1016/j. tranpol.2007.10.005

Beckmann, K.J. (2020): Beispiele einer gelungenen Integration von Raum- und Verkehrsentwicklung. In: Reutter, U.; Holz-Rau, C.; Albrecht, J.; Hülz, M. (eds.): Wechselwirkungen von Mobilität und Raumentwicklung im Kontext gesellschaftlichen Wandels. Hannover, 270-289. = Forschungsberichte der ARL 14 .

Beckmann, K.J.; Gies, J.; Thiemann-Linden, J.; Preuß, T. (2011): Leitkonzept - Stadt und Region der kurzen Wege. Gutachten im Kontext der Biodiversitätsstrategie. Dessau-Roßlau. = UBA-Texte 48/2011.

Busscher, T.; Tillema, T.; Arts, J. (2013): Revisiting a programmatic planning approach: managing linkages between transport and land use planning. In: Planning The- ory and Practice 14, 4, 492-508. https://doi.org/10.1080/ 14649357.2013.845685

Clark, C. (1958): Transport: Maker and Breaker of Cities. In: Town Planning Review 28, 4, 237-250.

Curtis, C. (2008): Planning for sustainable accessibility: The implementation challenge. In: Transport Policy 15, 2, 104-112. https://doi.org/10.1016/j.tranpol.2007.10. 003

Dortmunder Stadtwerke (2019): Bus und Bahn im Überblick. Nahverkehrsbroschüre. Dortmund.

Dziekan, K.; Zistel, M. (2018): Öffentlicher Verkehr. In: Schwedes, O. (ed.): Verkehrspolitik. Eine interdisziplinäre Einführung. Wiesbaden, 347-372. https://doi. org/10.1007/978-3-658-21601-6_16

Ewing, R.; Cervero, R. (2001): Travel and the Built Environment. A Synthesis. In: Transportation Research Record 1780, 1, 87-114. https://doi.org/10.3141/1780-10

Gawron, T. (2010): Steuerungstheorie, Policy-Forschung und Governance-Ansatz: Zum verfehlten GovernanceKonzept der Regionalforschung. Leipzig. = Schriftenreihe des Forschungsverbundes KoReMi 7.

Gertz, C.; Flämig, H.; Gaffron, P.; Polzin, G. (2018): Stadtverkehr. In: Schwedes, O. (ed.): Verkehrspolitik. Eine interdisziplinäre Einführung. Wiesbaden, 293-322. https://doi.org/10.1007/978-3-658-21601-6_14

Gil Solá, A.; Vilhelmson, B.; Larsson, A. (2018): Understanding sustainable accessibility in urban planning: Themes of consensus, themes of tension. In: Journal of Transport Geography 70, 1-10. https://doi.org/10.1016/ j.jtrangeo.2018.05.010

GPSM - German Partnership for Sustainable Mobility (2015): Recommendations for Mobility. Master Planning. Dresden.

Handy, S. (2005): Critical Assessment of the Literature on the Relationships Among Transportation, Land Use, and Physical Activity. https://citeseerx.ist.psu.edu/viewdoc/ download?doi=10.1.1.471.2645\&rep=rep1\&type=pdf (10.02.2021).

Holz-Rau, C. (2018): Verkehr und Verkehrswissenschaft. In: Schwedes, O. (ed.): Verkehrspolitik. Eine interdisziplinäre Einführung. Wiesbaden, 115-139. https://doi. org/10.1007/978-3-658-21601-6_6

Holz-Rau, C.; Scheiner, J. (2020): Mobilität und Raumentwicklung im Kontext des gesellschaftlichen Wandels - Schlussfolgerungen für Politik, Planungspraxis und Forschung. In: Reutter, U.; Holz-Rau, C.; Albrecht, J.; Hülz, M. (eds.): Wechselwirkungen von Mobilität und Raumentwicklung im Kontext gesellschaftlichen Wandels. Hannover, 380-408. = Forschungsberichte der ARL 14.

Hooghe, L.; Marks, G. (2003): Unraveling the central state, but how? Types of multi-level governance. In: American 
Political Science Review 97, 2, 233-243. https://doi.org/ $10.1017 /$ S0003055403000649

Hrelja, R. (2015): Integrating transport and land-use planning? How steering cultures in local authorities affect implementation of integrated public transport and landuse planning. In: Transportation Research Part A: Policy and Practice 74, 1-13. https://doi.org/10.1016/j.tra.2015. 01.003

Hull, A. (2008): Policy integration: What will it take to achieve more sustainable transport solutions in cities? In: Transport Policy 15, 2, 94-103. https://doi.org/10. 1016/j.tranpol.2007.10.004

Kennedy, C.; Miller, E.; Shalaby, A.; Maclean, H.; Coleman, J. (2005): The Four Pillars of Sustainable Urban Transportation. In: Transport Reviews 25, 4, 393-414. https://doi.org/10.1080/01441640500115835

Knieling, J.; Klindworth, K. (2016): Climate adaptation governance in cities and regions: framework conditions, theoretical concepts and research questions. In: Knieling, J. (ed.): Climate Adaptation Governance in Cities and Regions. Theoretical Fundamentals and Practical Evidence. Chichester, 1-20. https://doi.org/10.1002/ 9781118451694.ch1

Koglin, T. (2015): Organisation does matter - planning for cycling in Stockholm and Copenhagen. In: Transport Policy 39, 55-62. https://doi.org/10.1016/j.tranpol.2015.02. 003

Landeshauptstadt Hannover (2011): Masterplan Mobilität 2025. Hannover.

Leite, T.; Leiren, M.D.; Zibell, B.; Fürst, D.; Löb, S.; Lauridsen, H. (2008): Integrating Land Use and Transport Planning: Does Regional Governance Matter? Oslo. = TØI Report 958b-2008.

Levin-Keitel, M.; Othengrafen, F. (2016): Planungskultur - auf der Suche nach einem kontemporären Verständnis räumlicher Planung? In: disP - The Planning Review 52, 4, 76-89. https://doi.org/10.1080/02513625.2016. 1273672

Litman, T. (2020): Land Use Impacts on Transport. How Land Use Factors Affect Travel Behavior. http://www. vtpi.org/landtravel.pdf (11.02.2021).

Lowe, M.; Whitzman, C.; Giles-Corti, B. (2018): HealthPromoting Spatial Planning: Approaches for Strengthening Urban Policy Integration. In: Planning Theory and Practice 19, 2, 180-197. https://doi.org/10.1080/ 14649357.2017.1407820

LSN - Landesamt für Statistik Niedersachsen (2020): 02 Bevölkerung nach Geschlecht; Fläche; Bevölkerungsdichte (Gemeinde; Zeitreihe). LSN-Online: Tabelle Z100001G. https://www1.nls.niedersachsen.de/statistik/ html/default.asp (02.02.2020).

Marsden, G.; May, A.D. (2006): Do institutional arrange- ments make a difference to transport policy and implementation? Lessons for Britain. In: Environment and Planning C: Government and Policy 24, 5, 771-789. https://doi.org/10.1068/c0543

Marshall, S.; Banister, D. (2007): Introduction. In: Marshall, S.; Banister, D. (eds.): Land use and transport: European research towards integrated policies. Amsterdam, $1-4$.

Mayring, P. (2000): Qualitative Inhaltsanalyse. In: Forum: Qualitative Sozialforschung 1, 2, 20. https://doi.org/10. 17169/fqs-1.2.1089

Mu, R.; De Jong, M. (2016): A network governance approach to transit-oriented development: Integrating urban transport and land use policies in Urumqi, China. In: Transport Policy 52, 55-63. https://doi.org/10.1016/ j.tranpol.2016.07.007

Peters, B.G. (1998): Managing Horizontal Government. The Politics of Co-Ordination. In: Public Administration 76, 2, 295-311. https://doi.org/10.1111/1467-9299. 00102

Pozoukidou, G.; Chatziyiannaki, Z. (2021): 15-Minute City: Decomposing the New Urban Planning Eutopia. In: Sustainability 13, 2, 928. https://doi.org/10.3390/ su13020928

Priebs, A. (2014): Regional Government and Regional Planning in the Hanover Region. In: Quaestiones Geographicae 33, 4, 101-109. https://doi.org/10.2478/ quageo-2014-0053

Pucher, J.; Buehler, R. (2008): Making Cycling Irresistible: Lessons from The Netherlands, Denmark and Germany. In: Transport Reviews 28, 4, 495-528. https://doi.org/10. 1080/01441640701806612

Region Hannover (2011): Verkehrsentwicklungsplan pro Klima (VEP pro Klima). Hannover.

Region Hannover (2015): Unser Fahrplan für die Zukunft. Broschüre zum Nahverkehrsplan 2015. Hannover. = Beiträge zur regionalen Entwicklung 138.

Region Hannover (2016): Beschreibende Darstellung zum Regionalen Raumordnungsprogramm Region Hannover 2016. Hannover.

Rode, P. (2019): Urban planning and transport policy integration: The role of governance hierarchies and networks in London and Berlin. In: Journal of Urban Affairs 41, 1, 39-63. https://doi.org/10.1080/07352166.2016.1271663

Sager, F. (2007): Making Transport Policy Work: Polity, Policy, Politics and Systematic Review. In: Policy and Politics 35, 2, 269-288. https://doi.org/10.1332/ 030557307780712951

Schermerhorn, J.R. (1975): Determinants of interorganizational cooperation. In: Academy of Management Journal 18, 4, 846-856. https://doi.org/10.5465/255382

Schwedes, O. (2018): Verkehrspolitik als Gesellschaftspoli- 
tik. In: Schwedes, O. (ed.): Verkehrspolitik. Eine interdisziplinäre Einführung. Wiesbaden, 3-24. https://doi. org/10.1007/978-3-658-21601-6_1

Stadt Dortmund (2004): Flächennutzungsplan der Stadt Dortmund. Erläuterungsbericht 2004. Dortmund.

Stadt Dortmund (2014): Mobilitätsbefragung 2013. Dortmund. https://www.dortmund.de/media/p/ stadtplanungs_und_bauordnungsamt/stadtplanung_ bauordnung_downloads/verkehrsplanung/Vorlage_ Mobilitaetsverhalten.pdf (10.03.2021).

Stadt Dortmund (2018): Masterplan Nachhaltige Mobilität für die Stadt. Dortmund.

Stadt Dortmund (2021): Statistisches Jahrbuch 2020. Dortmund.

Stead, D. (2008): Institutional aspects of integrating transport, environment and health policies. In: Transport Policy 15, 3, 139-148. https://doi.org/10.1016/j.tranpol. 2007.12.001

Stead, D.; De Jong, M. (2006): Supportive Institutional Conditions for the Integration of Transport, Environment and Health Issues in Policy-Making. In: United Nations Economic Commission for Europe and World Health Organization Regional Office for Europe (eds.): Practical Guidance on Institutional Arrangements for Integrated Policy and Decision Making. Geneva, 3-48. https://doi. org/10.13140/RG.2.2.34429.00482

Stead, D.; Geerlings, H. (2005): Integrating Transport, Land Use Planning and Environment Policy. In: Innovation 18, 4, 443-453. https://doi.org/10.1080/13511610500384194 Stead, D.; Meijers, E. (2009): Spatial Planning and Pol- icy Integration: Concepts, Facilitators and Inhibitors. In: Planning Theory and Practice 10, 3, 317-332. https:// doi.org/10.1080/14649350903229752

Te Brömmelstroet, M.; Bertolini, L. (2010): Integrating land use and transport knowledge in strategy-making. In: Transportation 37, 1, 85-104. https://doi.org/10.1007/ s11116-009-9221-0

Tennøy, A.; Øksenholt, K.V. (2018): The Impact of Changed Structural Conditions on Regional Sustainable Mobility Planning in Norway. In: Planning Theory and Practice 19, 1, 93-113. https://doi.org/10.1080/14649357.2017. 1408135

Thomas, R.; Pojani, D.; Lenferink, S.; Bertolini, L.; Stead, D.; van der Krabben, E. (2018): Is transit-oriented development (TOD) an internationally transferable policy concept? In: Regional Studies 52, 9, 1201-1213. https:// doi.org/10.1080/00343404.2018.1428740

UBA - Umweltbundesamt (2017): Die Stadt für Morgen. Umweltschonend mobil - lärmarm - grün - kompakt durchmischt. Dessau-Roßlau.

Utriainen, R.; Pöllänen, M. (2018): Review on mobility as a service in scientific publications. In: Research in Transportation Business and Management 27, 15-23. https:// doi.org/10.1016/j.rtbm.2018.10.005

van Wee, B. (2002): Land use and transport: research and policy challenges. In: Journal of Transport Geography 10, 4, 259-271. https://doi.org/10.1016/S09666923(02)00041-8

VRR - Verkehrsverbund Rhein-Ruhr (2017): VRR-Nahverkehrsplan 2017. Bericht. Gelsenkirchen. 